\title{
MEPERIDINE-PROMETHAZINE COMBINATION AND LEARNING FUNCTION OF MICE AND OF THEIR PROGENY
}

\author{
Jack Chalon, laura Walpert, Sivam Ramanathan, Mark Eisner, Chau-Kvei Tang, \\ Robert Katz, and Herman Turndorf
}

\begin{abstract}
Twenty mice aged three to four months and trained to find food in a six compartment maze after a 24 hour fast, were divided into two equal groups. For just over one month the group which had received intraperitoneal meperidine $3 \mu \mathrm{g} \cdot \mathrm{g}^{-1}$ and promethazine $1.66 \mu \mathrm{g} \cdot \mathrm{g}^{-1}$ performed significantly slower than the group which had received intraperitoneal physiological saline. Because of this marked effect, it was decided to investigate the action of the drug combination on brain development and to assess whether it produced permanent retardation in learning function. The dams of a second group of 12 mice were, therefore, given either the same dose of drug combination or saline. At the age of seven weeks, the six pups born to dams which had received intramuscular saline and the six born to dams which were given intramuscular promethazine with meperidine perforrned equally well in a series of tests conducted in a $\mathrm{T}$ maze and in the six compartment maze after a 24 hour fast. In the $\mathrm{T}$ maze they had to distinguish between the presence of food provided in diminishing amounts or no food. In the six compartment maze they were tested with multiple maze pattern sequences. Meperidine and promethazine given during early labor does not permanently affect the learning function of the progeny of mice.
\end{abstract}

KEY WORDS: TOXICITY, foetal, meperidine, promethazine; BraIN, learning function, mice.

WE HAVE SHOWN that halothane and enflurane permanently affected the learning function of murine progeny exposed to either anaesthetic in utero, both early and late in pregnancy. ${ }^{1}$ Promethazine and meperidine are often administered together to sedate women in labor. ${ }^{2}$ Both drugs are known to cross the placenta rapidly ${ }^{3,4}$ and to affect the behaviour of human infants during the first 36 hours of life. ${ }^{4}$ In preliminary trials, we have noted the profound and persistent effect of this drug combination on 7 to 12 week old mice. We have, therefore, attempted to test two hypotheses: (1) after receiving the drug combination, do trained adult mice forget their way through a maze which they had learned and (2) are the effects noted in adults permanently

Jack Chalon, M.D., Professor; Laura Walpert, B.A., Mark Eisner, B.A., and Robert Katz, B.A., Research Assistants; Chau-Kvei Tang, M.D., Research Scientist; Sivam Ramanathan, M.D., Associate Professor; Herman Turndorf, M.D., Professor and Chairman; Department of Anesthesiology, New York University Medical Center, 550 First Avenue, New York, N.Y., 10016, U.S.A

Reprint requests to: Jack Chalon, M.D., Anesthesiology H-1892, New York University Medical Center, 550 First Avenue, N.Y., N.Y. 10016, U.S.A. transmitted to the progeny of pregnant mice receiving promethazine and meperidine in early labor? The first problem was solved by studying the response of 10 ( 13 to 17 week old) mice before and after administration of the drug combination, in the same six compartment maze used to study the effects of volatile anaesthetics (figure 1). ${ }^{1}$ The second was resolved by assessing the response of six pups seven weeks of age which had been exposed to promethazine and meperidine in utero three to four hours before birth. They were tested in a $T$ shaped maze after a 24 hour fast, to see if they could distinguish between the presence or absence of food provided in a preset sequence. They were then further studied in the six compartment maze. The performance of all animals was compared to that of control groups which had received physiological saline.

\section{Methods}

Subjects for the study included 20 adult brown dominant mice (Jackson Laboratories), aged 13 to 17 weeks and 12 seven week old brown dominant pups born to brown dominant sires and

Can. Anaesth. Soc. J., vol, 29, no. 6, November 1982 


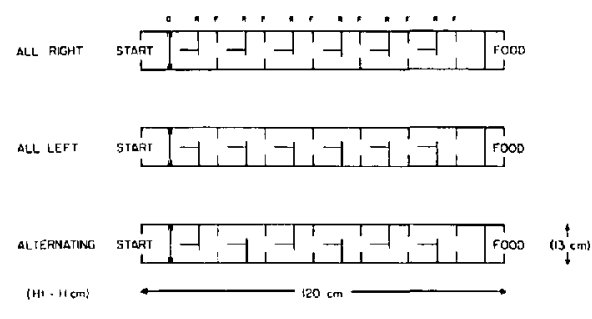

FIGure 1 Maze used to assess leaming function of mice. $\mathrm{D}=$ door admitting mice to the maze; $\mathrm{R}=$ reversible door; $F=$ fixed door; top: Maze set with all exits from all six compartments are to the right; middle, maze set so that all exits are on the left bottom, maze set so that exits alternate from right to left (reproduced by permission of Anesthesia and Analgesia).

dams, originating from the same laboratory. While in their cages all animals were fed the same diet (Wayne Lab-Blox, 8604-00, Allied Mills, Inc., Chicago, Ill.). Water was provided ad libitum.

Adult mice. All mice were trained to learn their way through a maze (figure 1) containing two $20 \mathrm{mg}$ food pellets (Precision Food Pellets, Noyes Co., Lancaster, N.Y.), after a 24 hour fast. The maze ${ }^{1}$ contained six compartments bisected by a central partition and with fixed and reversible exits. Thus three patterns could be set: (a) all exits on the right, (b) all exits on the left and (c) alternating right and left exits. The maze was used in that sequence. The time taken for each mouse to reach the food was noted. Three tests were conducted on each mouse for each maze setting every three days, to avoid underfeeding. When mice made no further statistically significant progress in all maze settings for three successive days, they were randomly divided into two equal groups. One group (C.1) received intraperitoneal physiological saline $2 \mathrm{ml}$ through a 25 gauge needle, and the second group (M.P.1) received intraperitoneal meperidine $3 \mu \mathrm{g}$ and promethazine $1.66 \mu \mathrm{g}$ per gram body weight, each in $1 \mathrm{ml}$ physiological saline through the same butterfly needle. Each group was then retested in the maze 90 minutes after injection until the 35th day, by an independent observer.

Pups of mice. Six of the seven week old pups born to dams which had received intramuscular physiological saline $2 \mathrm{ml}$ three hours before delivery (group C.2) and six of the seven week old pups born to dams which had received meperidine $3 \mu \mathrm{g}$ and promethazine $1.66 \mu \mathrm{g}$ per gram body weight (each in $1 \mathrm{ml}$ physiological saline) three and four hours respectively before delivery (group M.P.2) were tested in two mazes. All litters had been randomly restricted to three pups. The first maze was $\mathrm{T}$ shaped (figure 2) and covered by a transparent $T$ shaped acrylic plate. After a 24 hours fast each mouse was first placed in a darkened section at the bottom of the stem of the $\mathrm{T}$ behind a sash door. The maze was opened to the right by a central swivel door and the mouse allowed to reach four $(20 \mathrm{mg})$ food pellets, placed in a trough at the tip of the right wing of the $T$. Trials were then repeated for 2,1 and 0 pellets without covering the base of the maze. The sequence was performed twice with the maze open to the right and twice with the maze opened to the left. Experiments were conducted every three days during eight training days. In order to eliminate clues, the opaque roof plate on the compartment at the base of the stem of the $T$ was discarded and the maze was kept open on the right. The food pellet sequence was unaltered and all experiments repeated four times daily every three days, for 12 consecutive days. Time to reach the food was assessed in all instances.

Results were expressed as mean measurements ( \pm 1 S.E.M.). Statistical significance was assessed by Student's $t$ test, and for measurements in the $\mathrm{T}$ maze the chi square method was used (with the Yates correction factor for small numbers). Values of $P<0.05$ were considered significant.

Measurements in the T maze were assessed by a point scoring system. The time taken to reach the food trough for the four runs each day was

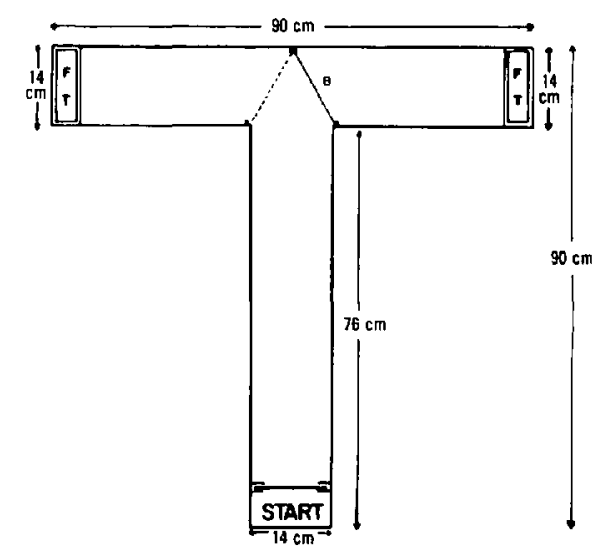

Figure 2 Diagram of $\mathrm{T}$ maze used to test seven week old pups. $\mathrm{B}=$ swivel door which opens right or left wing of maze. F.T. = food trough. 
TABLE I

\begin{tabular}{lcccccc}
\hline \hline Group & M.S. & P.I.T. & 90 minutes & 3 days & 9 days & 15 days \\
\hline \multirow{3}{*}{ C.1 } & R & $10 \pm 1.5$ & $11 \pm 1.3$ & $11 \pm 1.0$ & $10 \pm 1.1$ & $11 \pm 1.2$ \\
& L & $11 \pm 1.3$ & $10 \pm 1.0$ & $10 \pm 1.1$ & $11 \pm 1.2$ & $11 \pm 1.1$ \\
& A & $11 \pm 1.2$ & $10 \pm 1.4$ & $10 \pm 1.3$ & $11 \pm 1.2$ & $11 \pm 1.4$ \\
\hline \multirow{3}{*}{ M.P.1 } & R & $10 \pm 1.0$ & $18 \pm 2.0^{*}$ & $23 \pm 2.5 \dagger$ & $27 \pm 2.0 \dagger$ & $28 \pm 2.4 \dagger$ \\
& L & $10 \pm 1.5$ & $20 \pm 2.5 \dagger$ & $25 \pm 2.0 \dagger$ & $28 \pm 2.5 \dagger$ & $30 \pm 1.8 \dagger$ \\
& A & $11 \pm 1.8$ & $19 \pm 1.9 \dagger$ & $24 \pm 2.1 \dagger$ & $28 \pm 2.6 \dagger$ & $30 \pm 1.9 \dagger$ \\
\hline
\end{tabular}

Comparison between the performance in the six compartment maze of adult control mice (C. I) and adult mice receiving meperidine with promethazine (M.P.1). All figures indicate mean time to cover each maze pattern three times by 10 mice $( \pm 1$ S.E.M.) P.I.T. = preinjection trained. Minutes and days indicate post injection testing times. Statistical significance between the groups are: $*=P<0.005$ and $\dagger=P<0.0005$. The vertical line in group M.P.1 denotes significant deterioration in performance in all 3 maze pattems $(P<0.01)$. Five weeks later (not shown) there was no significant difference between the performance of both groups. M.S. = maze pattern setting.

noted. When the mean of all runs with the same number of pellets was statistically faster than when no food was present, one point was given. Thus each group could score between 0 and 3 points per testing day. Therefore, during the first eight days (maze open to right and left), the mice could score between 0 and 24 points, and during the next twelve days (maze only open to the right), 0 to 36 points. Statistical significance was assessed by the chi square method.

After all injections, the presence or absence of sleep or respiratory depression was noted.

\section{Results}

Adult mice covered the six compartment maze when it was open on the right in $34 \pm 10$ seconds, on the left in $38 \pm 15$ seconds, and alternately on the right and left in $40 \pm 16$ seconds. By the seventh training day these values had decreased to $10 \pm 1$ seconds, $11 \pm 2$ seconds and $12 \pm 2$ seconds respectively. For the next three days, they failed to make statistically significant progress, and by day 10 , they scored $10 \pm 1$ seconds, $11 \pm 1$ seconds and $11 \pm$ 1 second. When they were randomly divided into 2 groups (C.1 and M.P.1), there was no significant difference between the scores of either group (Table I). After the injection of saline, the performance of group C.1 did not vary significantly. However, group M.P.1 mice performed statistically significantly slower than controls for the first 15 days. By the third training period after injection, their performance was significantly slower than immediately preceding the injection $(\mathrm{P}<0.01)$ for all maze settings. By the 35 th day following injection there was no difference between the performance of groups M.P. 1 and C.1.
Both groups C. 2 and M.P. 2 performed statistically similarly in the $T$ maze. When it was opened alternatingly to the right and left, group C. 2 scored 21 out of 24 points, and group M.P. 2 scored 18 out of 24 (not significant). When the maze was open only to the right, group C.2 scored 16 out of 36 points and group M.P.2 scored 19 out of 36 points (not significant). In the six compartment maze (Table II) there was no significant difference between the performance of the two groups. When only the alternate maze pattem was used, groups C. 2 and M.P. 2 improved significantly by the third day of training ( $\mathrm{P}<$ 0.01 and $P<0.05$ respectively). When only the right and left maze patterns were used sequentially, groups C.2 and M.P.2 also improved significantly by the third training day $(\mathrm{P}<0.01$ and $P<0.05$ respectively). When all maze patterns were introduced (sequentially right, left and alternate) there was no significant difference between groups M.P.2 and C.2.

No mice slept or exhibited respiratory depression after drug administrations.

\section{Discussion}

More elaborate tests were done on pups than on adult mice. It was necessary to assess the effect of the drugs on brain development. The T maze tested sequential learning ability and the six compartment maze was further complicated to obtain maximal information on spatial orientation.

The intraperitoneal or intramuscular doses of meperidine and promethazine were in excess of recommended clinical intramuscular doses for $70 \mathrm{~kg}$ humans (meperidine 50-100 $\mathrm{mg}$ and promethazine $20-50 \mathrm{mg}$ ). ${ }^{5}$ Corresponding ex- 
TABLE II

\begin{tabular}{|c|c|c|c|c|c|c|}
\hline Group & M.S. & Day 1 & Day 3 & Day 5 & Day 7 & Day 10 \\
\hline $\begin{array}{l}\text { C.2 } \\
\text { M.P.2 }\end{array}$ & $\begin{array}{l}\mathrm{A} \\
\mathrm{A}\end{array}$ & $\begin{array}{l}27 \pm 7.7 \\
22 \pm 5.5\end{array}$ & $\begin{array}{r}6 \pm 1.0 \\
14 \pm 4.3\end{array}$ & $\begin{array}{l}7 \pm 1.2 \\
7 \pm 1.1\end{array}$ & $\begin{array}{l}4 \pm 0.7 \\
5 \pm 0.5\end{array}$ & $\begin{array}{l}5 \pm 0.5 \\
6 \pm 0.9\end{array}$ \\
\hline C. 2 & $\begin{array}{l}\mathbf{R} \\
\mathbf{L}\end{array}$ & $\begin{array}{l}19 \pm 5.0 \\
25 \pm 4.2\end{array}$ & $\begin{array}{r}6 \pm 0.9 \\
11 \pm 4.0\end{array}$ & $\begin{array}{r}5 \pm 0.5 \\
11 \pm 4.6\end{array}$ & $\begin{array}{l}4 \pm 0.3 \\
4 \pm 0.6\end{array}$ & $\begin{array}{l}4 \pm 0.4 \\
4 \pm 0.4\end{array}$ \\
\hline M.P.2 & $\begin{array}{l}\mathbf{R} \\
\mathbf{L}\end{array}$ & $\begin{array}{l}18 \pm 5.0 \\
25 \pm 4.4\end{array}$ & $\begin{array}{l}7 \pm 1.0 \\
7 \pm 0.5\end{array}$ & $\begin{array}{l}6 \pm 0.7 \\
7 \pm 0.8\end{array}$ & $\begin{array}{l}4 \pm 0.4 \\
5 \pm 0.7\end{array}$ & $\begin{array}{l}4 \pm 0.4 \\
4 \pm 0.3\end{array}$ \\
\hline Group & M.S. & Day 13 & Day 15 & Day 17 & Day 19 & Day 22 \\
\hline C. 2 & $\begin{array}{l}\text { R } \\
\mathrm{L} \\
\mathrm{A}\end{array}$ & $\begin{array}{r}4 \pm 0.4 \\
4 \pm 1.0 \\
11 \pm 2.9\end{array}$ & $\begin{array}{l}4 \pm 0.5 \\
5 \pm 0.5 \\
5 \pm 0.9\end{array}$ & $\begin{array}{l}3 \pm 0.2 \\
4 \pm 0.6 \\
6 \pm 0.9\end{array}$ & $\begin{array}{l}3 \pm 0.2 \\
3 \pm 0.4 \\
4 \pm 0.4\end{array}$ & $\begin{array}{l}3 \pm 0.2 \\
4 \pm 0.6 \\
5 \pm 0.8\end{array}$ \\
\hline M.P.2 & $\begin{array}{l}\mathbf{R} \\
\mathrm{L} \\
\mathrm{A}\end{array}$ & $\begin{array}{l}3 \pm 0.1 \\
3 \pm 0.2 \\
8 \pm 0.8\end{array}$ & $\begin{array}{l}3 \pm 0.2 \\
4 \pm 0.4 \\
6 \pm 1.0\end{array}$ & $\begin{array}{l}4 \pm 0.3 \\
4 \pm 0.2 \\
5 \pm 0.7\end{array}$ & $\begin{array}{l}4 \pm 0.6 \\
4 \pm 0.5 \\
5 \pm 0.7\end{array}$ & $\begin{array}{l}4 \pm 0.7 \\
4 \pm 0.3 \\
4 \pm 0.3\end{array}$ \\
\hline
\end{tabular}

Comparison between performance, in six compartment maze, of control pups (C.2) and pups which were exposed to the drug combination (M.P.2) M.S. = maze setting, $R=$ right, $L=$ left and $A=$ alternate mazc patterns. The upper two rows represent tests performed in alternate pattern and the next four rows in the right and left pattern, on days $1,3,5,7$, and 10 days of training. The last six rows indicate retraining in all maze patterns on days $13,15,17,19$ and 22 of training. For paired statistical significance, $\mathrm{P}<0.05=$ one vertical line, $\mathrm{P}<$ $0.025=$ two vertical lines, $\mathrm{P}<0.01=$ three vertical lines. All unpaired data are not significant. All figures are the mean of three runs by six mice ( \pm 1 S.E.M.)

perimental doses were meperidine $210 \mathrm{mg}$ and promethazine $116 \mathrm{mg}$. Since promethazine potentiates the narcotic effect of meperidine, ${ }^{5}$ its dosage was increased hand in hand with that of meperidine. The well known tolerance of mice to narcotics ${ }^{6}$ prompted us to use these doses.

The marked prolonged effect of the drug combination in adult mice was shown. However the progeny of mice which were exposed to meperidine and promethazine during pregnancy performed as well as controls in all tests, at and after the age of seven weeks. All newly born mice were pink, moved their limbs and suckled without difficulty. Tests in the $T$ maze were conducted at first with three cues: (1) moving out of the dark into the maze, (2) finding food alternatingly in the right or left wing of the maze, and (3) finding decreasing amounts of food followed by no food. When the first two cues were removed performance deteriorated, but there was no significant difference between the performance of the mice exposed to the drugs and the performance of the controls. It was impossible to administer drugs intraperitoneally in pregnant mice. Accidental intrauterine injection might have altered results and caused fatalities. It takes approximately one hour for drugs given intramuscularly to reach the foetus. ${ }^{2}$ Thus the timing of the injections three to four hours before delivery should have allowed ample time for them to enter the foetal circulation. Our timing was based on 21 days following a 24 hour mating period, before administering the injection. At first we were under the impression that the injections had induced labour. However subsequent similar injections proved us wrong.

(Humane standards equal to those described by the American Physiological Society were used throughout the study.)

\section{REFERENCES}

1. Chalon, J, Tano, C-K., Ramanathan, S., EISNER, M., Katz, R. \& TURNDORF, H. Exposure to halothane and enflurane affects learning function of murine progeny. Anesth Analg 60 : 794 (1981).

2. MARX, G.F. \& ORKIN, L.R. Physiology of Obstetric Anesthesia. Ist edition, Springfield, Illinois. Charles C. Thomas (1969) p. 85.

3. Ibid, p. 145 .

4. Ibid, pp. 85 and 145 .

5. Goodman, A.G., Goodman, L.S. \& Gilman A. GoOdMan and Gilman's: The pharmacologic Basis of Therapeutics. 6th Edition, New York, McMillan Co. (1980) p. 516

6. WAY, E.L., LOH, H.H. \& SHEW, F-H. Simultaneous quantitative assessment of morphine tolerance and physical dependence. J. Pharmacol. Exper. Therap. 167: 1 (1969). 


\section{RÉSUMÉ}

Vingt souris âgées de trois à quatre mois et entrânées à rechercher de la nourriture dans un labyrinthe à six compartiments après un jeûne de 24 heures ont étê reparties en deux groupes égaux. Après un peu plus d'un mois, le groupe qui avait reçu mépéridine $3 \mu \mathrm{g} \cdot \mathrm{g}^{-1}$ et prométhazine $1.66 \mu \mathrm{g} \cdot \mathrm{g}^{-1}$ en injection intrapéritonéale a exécuté sa tâche de façon significativement plus lente que celui qui avait reçu le soluté physiologique. A cause de cet effet marqué, il fut décidé d'étudier l'action des médicaments utilisés sur le développement cérébral et d'évaluer si elles produisaient un retard permanent de la fonction d'apprentissage. Dans un second groupe, 12 souris fécondées reçurent les mêtmes dases soit de l'association médicamenteuse soit de soluté physiologique. A l'âge de sept semaines, les deux groupes de six petits nés des souris à qui on avait donné soit l'association mépéridine-prométhazine soit le soluté physiologique, ont également bien exécuté une série de tests conduits dans un labyrinthe en $T$ et dans celui à six compartiments après un jeùne de 24 heures. Dans le labyrinthe en $T$, la progéniture avait à distinguer entre de la nourriture foumie en quantité décroissante et l'absence de nourriture. Dans le labyrinthe à six compartiments, les tests furent menés en variant la confirmation du labyrinthc. La mépéridine et la prométhazine administrés au début du travail n'affectent done pas de façon permanente la faculté d'apprentissage de la progéniture des souris. 